\title{
PENERAPAN TEORI BELAJAR KONSTRUKTIVISME UNTUK MENINGKATKAN HASIL BELAJAR MAHASISWA PADA MATA KULIAH MATEMATIKA DASAR
}

\author{
Endang Suprapti \\ ${ }^{1}$ Universitas Muhammadiyah Surabaya, Jl. Sutorejo No.59, Surabaya \\ endangumsurabaya@gmail.com
}

\begin{abstract}
Abstrak
Matematika dasar merupakan matakuliah dasar yang diberikan kepada mahasiswa di awal semester pada program studi pendidikan matematika, fakultas keguruan dan ilmu pendidikan Universitas Muhammadiyah Surabaya. Pada umumnya mahasiswa baru motivasinya masih tinggi dalam belajar dengan semangat yang tinggi, sehingga penting untuk meningkatkan semangat tersebut dengan hasil balajar yang baik. Hasil belajar yang baik tentunya harus didukung dengan proses perkuliahan yang mendukung dan kondusif. Tentunya proses yang kondusif didukung dengan persiapan dan penerapan model pembelajaran yang menarik. Berdasarkan permasalahan tersebut dilaksanakan penerapan teori belajar konstruktivisme untuk meningkatkan hasil belajar mahasiswa pada matakuliah matematika dasar. Berdasarkan hasil penelitian dapat disimpukan bahwa hasil belajar mahasiswa mengalam peningkatan sebesar $29,25 \%$ dari siklus 1 kesiklus 3 disamping itu respon mahasiswa positif sebesar $90 \%$.
\end{abstract}

Kata Kunci: Teori Belajar, Konstruktivisme, Hasil Belajar

\begin{abstract}
Mathematics of Basic is the basic course given to students at the beginning of the study on mathematics education program, teacher training and education faculty of Muhammadiyah University of Surabaya. In general, new students are still high motivation in learning with high spirits, so it is important to improve the spirit with good learning results. A good learning result must be supported by a supportive and conducive lecturing process. Certainly a conducive process is supported by the preparation and application of an interesting learning model. Based on these problems implemented the application of constructivism learning theory to improve student learning outcomes in the mathematic of basic course. Based on the results of the study it can be concluded that the students' learning results increased $29,25 \%$ of cycle 1 to 3 in addition to positive student response by $90 \%$.
\end{abstract}

Keywords: Learning theory, Constructivism, learning outcomes

\section{Pendahuluan}

Matematika dasar merupakan matakuliah dasar yang diberikan kepada mahasiswa di awal semester pada program studi pendidikan matematika, fakultas keguruan dan ilmu pendidikan Universitas Muhammadiyah Surabaya. Pada umumnya mahasiswa baru motivasinya masih tinggi dalam belajar dengan semangat yang tinggi, sehingga penting untuk meningkatkan semangat tersebut dengan hasil balajar yang baik. Hasil belajar yang baik tentunya harus 
didukung dengan proses perkuliahan yang mendukung dan kondusif. Tentunya proses yang kondusif didukung dengan persiapan dan penerapan model pembelajaran yang menarik. Proses pembelajaran yang menarik dapat terlaksana dengan model pembalajaran yang sesuai dengan karakteristik siswa. Penerapa model pembelajaran dalam perkuliahan hal ini juga tidak lepas dengan pendekatan salah satunya pendekatan konstruktivisme.

Konstruktivisme sekarang banyak digunakan sebagai pendekatan-pendekatan dalam proses pembelajaran. Menurut Windschitl, dalam Abbeduto, (2004) Konstruktivisme pada dasarnya adalah suatu pandangan yang didasarkan pada aktivitas siswa dengan untuk menciptakan, menginterpretasikan, dan mereorganisasikan pengetahuan dengan jalan individual. Sejalan dengan pendapat tersebut, Schwandt (1994) mengatakan bahwa konstruktivisme adalah seperti interpretivis dan konstruktivis. Hal ini sejalan dengan pendapat von Glaserfeld (1987) bahwa pengetahuan bukanlah suatu komunikasi dan komoditas dapat dipindahkan dan tak satu pengantar-pun itu ada.

Mahasiswa dalam mengkonstruksi pengetahuan mereka maka diperlukan interaksi dengan lingkungannya sehingga tentunya dalam pelaksanaan pembelajaran dapat diterapkan dengan model pembelajaran yang tepat sesuai agar interaksi bisa berjalan dengan baik dan pemahaman konsep mahasiswa bisa berjalan dengan lancar. Dalam penelitian ini, peneliti menggunakan model pembelajaran kooperatif tipe TPS (Think Pair Share), dengan harapan selain menningkatkan hasil belajar mahasiswa. Model pembelajaran think pair share adalah salah satu model pembelajaran kooperartif dengan tipe siswa berdiskusi secara berpasangan, yang memberi kesempatan kepada setiap siswa untuk menunjukkan partisipasi kepada orang lain. Keunggulan teknik ini adalah optimalisasi partisipasi siswa (Lie: 2004).

Adapun definisi pembelajaran kooperatif tipe think pair share menurut Arends (dalam Komalasari, 2010: 84) yang menyatakan bahwa, model pembelajaran think pair share adalah suatu cara yang efektif untuk membuat variasi suasana pola diskusi kelas. Dengan asumsi bahwa semua resitasi atau diskusi membutuhkan pengaturan untuk mengendalikan kelas secara keseluruhan dan prosedur yang digunakan dalam think pair share dapat memberi murid lebih banyak waktu untuk berfikir, untuk merespon dan saling membantu. menurut Ibrahim (2000:40) tahapan-tahapan didalam model pembelajaran kooperatif tipe think pair share, yaitu antara lain sebagai berikut: (i) Berpikir (Thinking) Guru mengajukan pertanyaan yang berhubungan dengan pelajaran, kemudian meminta kepada siswa untuk memikirkan pertanyaan tersebut secara mandiri untuk beberapa saat. (ii) Berpasangan (Pairing) Guru meminta siswa berpasangan dengan siswa yang lain untuk mendiskusikan apa yang teah dipikirkannya pada tahap berpikir. Pada tahap ini setiap anggota pada kelompok 
membandingkan jawaban atau hasil pemikiran mereka dengan mendefinisikan jawaban yang dianggap paling benar atau paling meyakinkan. Dan (iii) Berbagi (Sharing) Guru meminta kepada pasangan untuk berbagi dengan seluruh kelas tentang apa yang telah mereka bicarakan. Keterampilan berbagi dalam seluruh kelas dapat dilakukan dengan menunjuk pasangan yang secara sukarela bersedia melaporkan hasil kerja kelompoknya atau bergiliran pasangan.

Berdasarkan permasalahan tersebut dilaksanakan penerapan teori belajar konstruktivisme untuk meningkatkan hasil belajar mahasiswa pada matakuliah matematika dasar.

\section{Metode Penelitian}

Penelitian ini merupakan jenis Penelitian Tindakan Kelas (PTK) dengan pendekatan deskriptif kualitatif. Penelitian terdiri dari 3 siklus dengan masing-masing siklus terdiri dari 2 pertemuan. Setiap siklus terdiri dari 3 tahap, yaitu perencanaan tindakan, pelaksanaan tindakan, dan refleksi tindakan. Sumber data yaitu mahasiswa prodi pendidikan matematika, Fakultas Keguruan dan Ilmu Pendidikan, Universitas Muhammadiyah Surabaya, dengan jumlah 30 mahasiswa. Materi yang digunakan dalam penelitian ini adalah Logika Matematika dengan rancangan penelitian sebagai berikut: Penelitian tindakan kelas ini dilaksanakan dalam 2 siklus. Setiap siklus dilaksanakan sesuai indikator yang ingin dicapai.

Adapun alur skema penilitian tindakan kelas (arikunto, 2008 : 16) sebagai berikut :

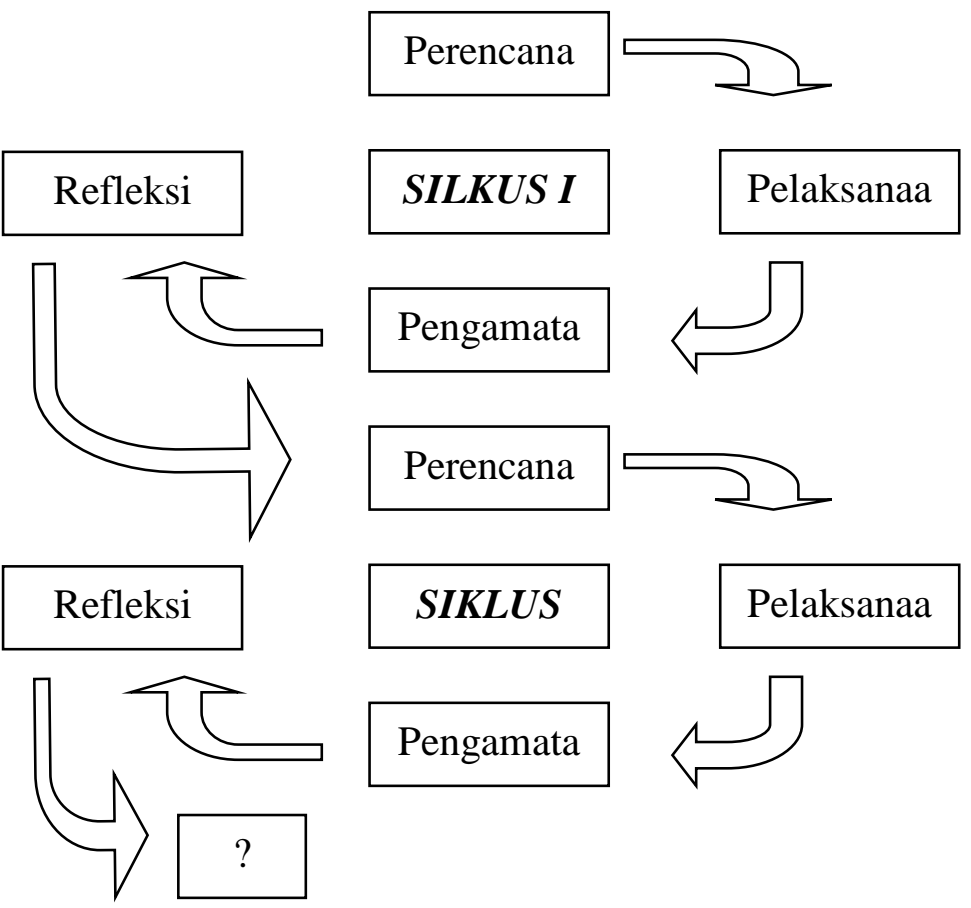

Gambar 1 Alur skema penelitian tindakan kelas 
Adapun rancangan dan langkah-langkah penelitian secara terperinci diuraikan sebagai berikut : Siklus 1, kegiatan awal (a) Mengamati proses pemebeljaran dan aktivitas mahasiswa saat kegiatan perkuliahan untuk mengetahui seberapa besar minat dan aktivitas mahasiswa saat mengikuti pembelajaran.(b) Mengobservasi nilai hasil belajar mahasiswa sebelum perkuliahan dilakukan dengan penerapan teori belajar konstruktivisme melalui mode kooperatif tipe TPS. Kegiatan ini dlakukan hal yang sama pada siklus ke 2 dan siklus ke 3 dalam setiap akhir siklus selalu dilakukan refleksi dan di awali dengan perencanaan menyusun Rencana Pelaksanaan Pembelajaran (RPP). Membuat instrument penelitian antara lain Lembar Kerja mahasiswa (LKM), Kuis, Lembar Tes Hasil Belajar, lembar observasi keterlaksanaan pembelajaran dan aktivitas mahasiswa.

\section{Hasil dan Pembahasan}

Berdasarkan pelaksanan penelitian yang dilaksanakan pada bulan oktober tahun 2017n yang terdiri dari tiga siklus penelitian hasil penelitian ini dikelompokan dalam empat bagian yaitu keterlaksanaan pembelajaran, hasil belajar mahasiswa, aktivitas mahasiswa dan respon mahasiswa.

\section{a. Keterlaksanaan Pembelajaran}

Hasil analisis data menunjukkan bahwa rata-rata persentase keterlaksanaan kegiatan pembelajaran dengan penerapan teori belajar konstruktivisme pada matakuliah matematika dasar mengalami peningkatan setiap siklusnya. Adapun prosentase keterlaksanan kegiatan pembelajaran setiap siklusnya dapat dilihat pada tabel ber 1 berikut:

Tabel 1 Keterlaksanan Kegiatan Pembelajaran

\begin{tabular}{ccccc}
\hline No & Siklus & \multicolumn{2}{c}{$\begin{array}{c}\text { Prosentase Keterlaksanaan } \\
\text { Pembelajaran }\end{array}$} & \multirow{2}{*}{$\begin{array}{c}\text { Rata-rata } \\
(\%)\end{array}$} \\
\cline { 3 - 4 } & & Pertemuan 1 & Pertemuan 2 & \\
\hline 1 & Siklus 1 & 78,02 & 82,05 & 80,04 \\
\hline 2 & Siklus 2 & 85,01 & 87,06 & 86,04 \\
\hline 3 & Siklus 3 & 88,03 & 90,06 & 89,05 \\
\hline
\end{tabular}

Berdasarkan tabel 1 di atas keterlaksanaan kegiatan pembelajaran mengalami peningkata setiap siklusnya hal ini dapat dilihat dari sklus 1 sampai siklus ketiga mengalami peningkatan dari 78,02\% menjadi 89,05\% atau meningkat 10,03\% Peningkatan persentase keterlaksanaan kegiatan pembelajaran terjadi karena pada setiap pertemuan pembelajaran, dosen selalu melaksanakan kegiatan perencanaan pembelajaran dengan model perencanaan lesson study dengan tim matakuliah matematika dasar. Penerapan kegiatan lesson study dapat 
meningkatkan kualitas dosen dan pembelajaran karena dosen bekerja secara kolaboratif atau diskusi bersama dengan dosen yang lain/anggota tim lesson study, sehingga dosen selalu mendapatkan masukan dari dosen yang lain baik dalam persiapan maupun pelaksanaan pembeljaran. Masukan yang diberikan kepada dosen model yaitu tentang rancangan pembelajaran yang akan digunakan melalui kegiatan plan dan perbaikan pembelajaran melalui kegiatan see, sehingga dosen dapat saling belajar satu sama lain dan memperbaiki perencanaan pembelajaran pada pertemuan selanjutnya.

Kegiatan saling belajar akan memberikan manfaat kepada seluruh anggota melalui program lesson study untuk berbagi pengalaman tentang kegiatan pembelajaran dan sarana perbaikan diri, sehingga dapat meningkatkan kualitas/ profesionalisme masing-masing dosen. Peningkatan profesionalisme dosen akan meningkatkan kualitas pembelajaran, sehingga kualitas siswa juga dapat mengalami peningkatan. Sesuai dengan pendapat dari (Lewis, 2002 dalam Ibrohim 2011:6), yaitu dosen yang melaksanakan kegiatan lesson study akan menjadi dosen yang professional dan inovatif karena beberapa alasan, antara lain: (1) dapat menentukan tujuan dan metode pembelajaran yang aktif; (2) memperdalam pengetahuan tentang mata pelajaran yang disampaikan oleh guru model; (3) merencanakan pembelajaran se-cara kolaboratif; (4) mengkaji cara belajar dan perilaku siswa secara teliti; dan (5) melakukan refleksi terhadap pembelajaran yang telah dilakukan.

Hambatan yang ditemui dalam melaksanakan kegiatan lesson study adalah kurang-nya pemahaman anggota tim tentang cara melaksanakan kegiatan lessson study dengan benar. Kegiatan lesson study yang dilaksanakan bersama tim memiliki kekurangan, terutama pada saat kegiatan see. Kegiatan see yang dilakukan oleh tim belum terlaksana secara utuh sesuai dengan aturan pelaksanaan kegiatan see. Kegiatan see dilakukan dengan mengutarakan refleksi diri secara bergiliran, dimulai dari guru model yang dilanjutkan dengan refleksi dari para observer yang dilengkapi de-ngan solusi mengatasi permasalahan hasil temuan observer selama mengamati kegiatan pembelajaran tanpa ada moderator. Solusi untuk mengatasi permasalahan ini adalah dengan memahami cara pelaksanaan kegiatan lesson study dengan baik bersama tim sebelum melakukan kegiatan lesson study.

Kurangnya kesungguhan anggota tim dalam melakukan pengamatan kegiatan pembelajaran juga menjadi hambatan pelaksanaan kegiatan lesson study. Solusi mengatasi hambatan ini adalah dengan berkomunikasi secara efektif kepada seluruh anggota tim dan mencari solusi permasalahan bersama-sama, sehingga kegiatan perencanaan pembelajaran dengan metode lesson study dapat berjalan dengan lancar. Hambatan lain yang dialami observer dalam melaksanakan lesson study adalah kurangnya sikap dosen model untuk 
menerima masukan dari observer lain dan cenderung menganggap benar pemikirannya sendiri. Kegiatan lesson study yang tidak dilaksanakan dengan bijak dan adanya sifat egois dari salah satu anggota tim dapat membuat kegiatan lesson study tidak berjalan dengan lancar.

Solusi untuk mengatasi hambatan pelaksanaan kegiatan pembelajaran yaitu dengan melakukan variasi teknik pembelajaran setiap pertemuan. Teknik yang divariasi antara lain pembagian kelompok dan jumlah pertanyaan yang dibuat siswa. Teknik mengubah anggota kelompok setiap topik pembelajaran dapat mengatasi kebosanan mahasiswa dalam mengikuti pembelajaran karena selalu mendapat-kan pasangan baru. Jumlah pertanyaan yang dibuat oleh siswa secara bertahap dari sedikit menjadi banyak akan meringankan kerja siswa dalam menjawab pertanyaan, sehingga siswa dapat mengikuti pembelajaran dengan maksimal dan tidak akan mengeluh dalam melaksanakan tugas.

\section{b. Hasil Belajar Mahasiswa}

Berdasarkan hasil pengamatan dan pengambilan data penelitian, hasil tes belajar mahasiswa menunjukan bahwa hasil belajar mahasiswa mengalami peningkatan setiap siklusnya, hal ini dapat dilihat pada tabel 2 berikut:

Tabel 2 Hasil belajar Mahasiswa Siklus 1-3

\begin{tabular}{lll}
\hline No & Keterangan & Nilai Rata-Rata \\
\hline 1 & Siklus 1 & 56,55 \\
\hline 2 & Siklus 2 & 78,25 \\
\hline 3 & Siklus 3 & 85,70 \\
\hline
\end{tabular}

Berdasarkan tabel 2 di atas menunjukan bahwa hasil belajar mahasiswa mengalami peningkatan setiap siklusnya dengan rata-rata siklus 1 sebesar 56,55, pada siklus ke 2 sebesar 78, 25\% dan pada siklus ke 3 sebesar 85,70. Sehingga dari siklus ke 1 sampai pada siklus ke-3 mengalami peningkatan sebesar 29,15.

\section{c. Aktivitas Mahasiswa}

Aktivitas mahasiswa merupakan bagian yang penting untuk diamati dalam menentuka proses pembelajaran sudah berjalas sesuai yang direncanakan. Berdasarkan hasil penelitian aktivitas mahasiswa dapat dilihat dalam tabel 3 berikut:

Tabel 3 Aktifitas mahasiswa dari siklus 1 sampai 3

\begin{tabular}{lcccc}
\hline \multirow{2}{*}{ No } & \multirow{2}{*}{ Kategori } & \multicolumn{3}{c}{ Prosentase } \\
\cline { 3 - 5 } & & Siklus 1 & Siklus 2 & Siklus 3 \\
\hline 1 & Sangat Baik & 80,02 & 86,2 & 92 \\
\hline 2 & Baik & 10,8 & 13,2 & 8 \\
\hline
\end{tabular}




\begin{tabular}{lllll}
\hline 3 & Cukup & 2 & 0 & 0 \\
\hline 4 & Kurang & 0 & 0 & 0 \\
\hline
\end{tabular}

Berdasarkan data tabel 3 di atas terlihat bahwa terjadi peningkatan rata-rata aktivitas mahasiswa dalam pembelajaran mata kuliah matematika dasar dari siklus 1 sampai siklus ke 3 prosentase terbesar pada kategori sangat baik dan kategori baik.

Hasil belajar afektif dapat ditingkatkan melalui penerapan teori belajar konstruktivisme dengan model pembelajaran kooperatif tipe Think Pair Shared (TPS). Pembelajaran menggunakan model pembelajaran kooperatif tipe Think Pair Shared (TPS) dapat melatih mahasiswa untuk berinteraksi pasangannya, bekerjasama dengan baik, dan membuat kesepakatan bersama untuk memberikan solusi/ penyelesaian terbaik dari masalah yang didapatkan. Kegiatan bekerja sama dan bermusyawarah dengan tim dapat melatih siswa untuk menumbuhkan sikap menghargai pendapat, menanggapi pendapat, melakukan penilaian terhadap pendapat teman, serta mencari solusi atas permasalahan yang diberikan oleh dosen, se-hingga mahasiswa dapat menyikapi suatu permasalahan dengan bijak.

d. Respon Mahasiswa

Respon mahasiswa terhadap proses pelaksanaan pembelajaran selama siklus 1 sampai dengan siklus ke 3 dapat terlihat pada tabel berikut:

Tabel 4 Hasil Respon Mahasiswa

\begin{tabular}{|c|c|c|c|c|}
\hline No & Uraian Pertanyaan & \multicolumn{2}{|c|}{ Respon } & Alasan \\
\hline \multirow[b]{2}{*}{1} & $\begin{array}{l}\text { Perasaan mahasiswa selama } \\
\text { mengikuti pembelajaran }\end{array}$ & Senang & $\begin{array}{c}\text { Tidak } \\
\text { Senang } \\
\end{array}$ & \multirow[b]{2}{*}{$\begin{array}{l}\text { hal baru, } \\
\text { langkahnya jelas }\end{array}$} \\
\hline & $\begin{array}{l}\text { dengan teori belajar } \\
\text { konstruktivisme dengan model } \\
\text { kooperatif TPS }\end{array}$ & 97 & 3 & \\
\hline \multirow{2}{*}{2} & $\begin{array}{l}\text { Pendapat mahasiswa terhadap } \\
\text { media pembelajaran dengan }\end{array}$ & Menarik & $\begin{array}{c}\text { Tidak } \\
\text { Menarik }\end{array}$ & \multirow{2}{*}{$\begin{array}{l}\text { menyenangkan, } \\
\text { lebih interaktif }\end{array}$} \\
\hline & $\begin{array}{l}\text { teori belajar konstruktivisme } \\
\text { dengan model kooperatif TPS }\end{array}$ & 93,5 & 6.5 & \\
\hline 3 & $\begin{array}{l}\text { Pendapat mahasiswa terhadap } \\
\text { LKS yang digunakan selama } \\
\text { pembelajaran. }\end{array}$ & 93.2 & 6,8 & $\begin{array}{l}\text { lebih tertantang, } \\
\text { langkah-langkah } \\
\text { mudah }\end{array}$ \\
\hline \multirow[b]{2}{*}{4} & Pendapat mahasiswa tentang & Jelas & Tidak Jelas & \multirow[b]{2}{*}{ mudah dipahami } \\
\hline & $\begin{array}{l}\text { banasa yang digunakan dalam } \\
\text { teori belajar konstruktivisme } \\
\text { dengan model kooperatif TPS, } \\
\text { LKS, Kuis dan THB. }\end{array}$ & 87.0 & 13.0 & \\
\hline 5 & Pendapat mahasiswa tentang & Setuju & Tidak Setuju & Belajar lebih \\
\hline
\end{tabular}




\begin{tabular}{|c|c|c|c|}
\hline & $\begin{array}{l}\text { mata pelajaran lain/materi lain } \\
\text { yang diajarkan dengan } \\
\text { menggunakan teori belajar } \\
\text { konstruktivisme dengan model } \\
\text { kooperatif TPS }\end{array}$ & 90.7 & $\begin{array}{l}\text { mudah dan } \\
\text { menyenangkan }\end{array}$ \\
\hline 6 & $\begin{array}{l}\text { Pendapat atau harapan } \\
\text { mahasiswa } \\
\text { pembelajaran dengan teori } \\
\text { belajar konstruktivisme dengan } \\
\text { model kooperatif TPS }\end{array}$ & dilanjutkan ke materi yang lain & \\
\hline
\end{tabular}

Berdasarkan tabel $4 \mathrm{di}$ atas respon mahasiswa terhadap proses pembelajaran dengan menerapkan teori belajar konstruktivisme dengan model kooperatif tipe Think Pair Share (TPS) pada mata kuliah matematika dasar menunjukkan bahwa respons siswa terhadap pembelajaran $97 \%$ positif.

\section{Simpulan dan Saran}

Berdasarkan hasil dan pembahasan penelitian penerapan teori belajar konstruktivisme dengan model pembelajaran kooperatif tipe Think Pair Shared (TPS) disimpulkan terdapat peningkatan hasil belajar mahasiswa kelas matematika dasar dengan ditunjukan prosentase peningkatan sebesar 29,25 dari siklus 1 sampai siklus ketiga. Hal ini juga di dukung oleh hasil pengamatan keterlaksanaan pembelajaran yang rata-rata di atas $80 \%$, aktivitas mahsiswa ratarata maksimal pada kategori sangat baik. Serta respon mahasiswa terhadap proses pembelajaran positif dengan prosentase rata-rata di atas $90 \%$.

Pembelajaran dengan pendekatan teori belajar konstruktivisme dapat digunakan sebagai variasi pembelajaran pembelajaran matematika dengan pemilihan materi yang tepat sehingga dapat merencanakan kegiatan pembelajaran dengan membuat perangkat pembelajaran terlebih dahulu. Hasil penelitian ini dapat digunakan sebagai dasar oleh peneliti lain yang hendak melakukan penelitian mengenai pembelajaran dengan menggunakan pendekatan teori belajar konstruktivisme dengan model kooperatif learning tipe Think Pair shared.

\section{Referensi}

Anita, Lie. 2004. Cooperatif Learning. Jakarta: Grasindo.Ibrahim, Muhsin dkk. 2000. Pembelajaran Kooperatif. Surabaya: University Press.

Arends, Richard I., 1997. Classroom Instruction and Management. McGraw-Hill.

Arikunto, Suharsimi. 2001. Dasar-dasar Evaluasi Pendidikan. Jakarta: Bumi Aksara. 2000. Manajemen Penelitian. Jakarta: Rineka Cipta. 
Arsyad, Azhar. 2010. Media Pembelajaran. Jakarta: Rajawali Pers.

HUdojo, Herman, 1988. Mengajar Belajar Matenatika. Jakarta: Departemen Pendidikan Nasional

Ibrahim, Muslimin, dkk. 2000. Pembejaran Kooperatif, University Press. Universitas Negeri Surabaya

Isjoni, 2007. Pembelajaran Kooperatif. Yogyakarta: Pustaka Pelajar.

Komalasari, Kokom. 2010. Pembelajaran Kontekstual; Konsep dan Aplikasi. Bandung: PT. Refika Aditama.

Nur, M. 2005. Pembelajaran Kooperatif. Surabaya: UNESA University Press

Pribadi, Benny A, 2009. Model Disain Sistem Pembelajaran, Jakarta: Dian Rakyat

Slavin, Robert E. 2009. Cooperative Learning. Bandung: Nusa Media

Slavin, R.E, 1994. Educational Psychology Theory Into Practices (Fourth Edition). Boston: Allyn and Bacon

Trianto. 2007. Model-model Pembelajaran Inovatif Berorientasi Konstruktivistik. Jakarta: Prestasi Pustaka. 